\title{
Contributions to the Morphology of the Mistletoe (Viscum album, L.).
}

$14 \mathrm{Y}$

SEIMAR SCHÖNLAND, Ph.D.

With Plate XVII.

DURING the past: few years I have repeatedly had oppertunitics of observing a large number of abnormalitics in the structure and arrangement of the organs of the mistletoc, many of which have been noticed before, while others are apparently new. They have led me to give interpretations to some morphologrical characters of this plant different from those hitherto given, and I therefore think they are worth describing.

In the present paper If propose to deal chicfly with the morphology of the flowering shoots, including both the arrangement and the general structure of the flowers. In order to make my rematrs more intelligible, I have included almost all that has been said on the subject by Wydler ${ }^{2}$ and Iichler ${ }^{2}$.

The mistletoe is dioccious ". The plants of the two sexes have on the whole the same structure. The axis of the seedling produces two cotyledons and a pair of foliage-leaves alternating with these. It then ceases to grow any further, but in the axils of the folinge-leaves buds ate produced which develop into branches the next ycar. Each branch bears at its basc two mintte opposite scalc-leaves, the prophylls of the new shoot ( $p, p$ in the diagrams); they are at right angles to the bract of the shoot ( $B$ in the diagrams). Near the top of

1 Jikorn, 1860,1$) .43$.

* Blitthendlingramme, ii. 1) $55^{2}$.

Only a single case in which a male plant had also produced some female flowers and fruits is mentioned by Masters in his Vegetnljle Terntolngy, p. 5on.

[Annals of Botany, Vo1. II. No. VII, November 1888. ] 
a branch two foliagc-leaves $(L, L$, Figs. $\mathrm{T}, 2$, ctc.) are usually found, which alternate with the prophylls, and are therefore median. During the first ycars the apex of each shoot is either nalicd, or it bears two more scale-leaves, which again alternate with the foliage-leaves, but the growth is always continued by buds springing from the axils of the latter, and thus the well-known pseudo-dichotomous structure of the mistletoc is produced. The foliage-leaves normally last only one scason, while the prophylls may remain for a period of eight or more years. In about the fourth or fifth year of the life of the plant a small capitate inflorescence is produced at the top of cach shoot.

It commonly happens that foliage-leaves or shoots are not developed in places where the general plan of the plant would lead us to expect them. The shoots especially maly remain dormant for several years. If only one shoot is developed, it often appears as the direct prolongation of its mother axis. If this goes on for several years a sympodium is produced which is frequently of considerable length. It also happens sometimes that new shoots are procluced in the axils of the prophylls, and thus false whorls of three to six shoots are formed. As this may be repeated in the case of the accessory shoots, their number may be increased still more, and Wydler ${ }^{1}$ found as many as twelve in one case; he also saw prophylls developed into foliage-leaves. Shoots bearing a whorl of three foliage-leaves are not rare, whereas whorls of four foliage-leaves ${ }^{2}$ are uncommon, but I found them in both male and female plants. The increase in the number of foliage-leaves seems on the whole to be more frequent in the male plants. As a rule, this is clue to the substitution of a trimerous or tetramcrous whorl for the normal dimerous whorl, as is shown by the fact that each of them may

1 Flom, $1860, \mathrm{I}^{2}, 445$.

"In one case I found live folinge-leaves in a rather irregular whort. This was due to the fasciation of two shoots, one bearing two, the other three lenves. 'The true nature of this abnormality was clenxy shown by the internote being groved, etc., also by the structure of the two inflorescences which terminated this double shoot. 


\section{of the Mistletoe (Viscum album, L.). $\quad 285$}

bear an axillary bud, and thus true whorls of thrce or four branches may also be produced. I have actually observed such true whorls of three and four branches. The structure of the inflorescence, moreover, corresponds usually to the number of foliagr-leaves, as we shall see later. In one case only, where three foliage-leaves occurred, they secmed to have arisen from the normal two leives. One of the three leaves was rather broad, and showed beginning of splitting at the apex, while two others werc about the normal size; but neither one nor the other of these hat, like the thired, a bud in its axil, there wals: however, it bud between them, which served, ats it were, ats a common axillary bucl for the two together (Fig. 3). It is probible. therefore, that they owed their origin to the splitting of one of the normal leaves. The odd leaf of the true trimerous whorls of foliage- leaves is al ways turned towards the axis (light. 4, 5 1), whereas the leaves of the tetramerous whorls are placed diagonally (Fig. 5 IT, 6).

The infloresecences alle usually found between the two foliageleaves, and normally consist of two lateral flowers at right angles to these leaves, and a terminal flower. Iatch of the former stancls in the axil of a small scale-leat, the two together thus forming a third whorl of lcaves $(s, s$, lighs. 5,2$)$. No more leaves atre borne directly by the primaty axis of each shoot in the male plants, but in the female plants the terminal flower is usually preceded by a fourth pair of leaves, which is like the one preceding it, and continues the regular decussate arrangement of leaves ${ }^{1}\left(s^{2}, s^{1}\right.$, Fign. 1). Where three or four foliage-leaves are borne by a shoot, the number of the upper scale-leaves is increatsed at the same rate; this is often also the case with the lateral flowers, but frequently their full number is not developed (Figs. 5 I and 5 II). Very often scale-leaves are only developed where foliage-leaves ought to be, either in the place of one or of both of a pair. This occurs chiefly in shoots which have been clormant one or more years. Very commonly these additional scale-leaves also bear flowers in their axils,

1 Grom a remark male by Wydler, Iilura, 1860, 1. 443, I conclude they may also bene llower's in their axils. 
and thus we get an inflorescence of five flowers, as represented in Fing. 7. Such an inflorescence has usually a short stalk, and is like the ordinary shoots provided with two prophylls at the base. Whole inflorescences or single flowers may also be formed in the axils of the prophylls of ordinary shoots.

The terminal flower of the male inflorescence is, as a rule, not preceded by scalc-leaves, as indicated above. 13ut Tofmeister ${ }^{1}$ has stated that they are present here, as in the female inflorescences. This is really often the case, although not observed by Iichler, but still the structure of the inflorescences in which it occurs is not the same as that of the female inflorescences. I only obsurved this apparent abnormality in inflorescences developed from dormant buds. I have represented it in lig. $8 \mathrm{I}$. It is shown there that in the abnormal calics the shoots of male plants have only three pairs of decussate leaves, as in the normal cases. The abnormality is at once unclerstood by comparing it with a case such as is represented in $\mathrm{Fig}$. 7 , and which I have explained alleady. If in such a case the two lateral flowers are not developed, as frecuently hiappens, a three-flowered inflorescence is produced which, it is truc, agrees in its general structure with the normal female inflorescences, but there is one difference (quite apart from the number of leaves) by means of which its true nature may be at: once detected. A normal female inflorescence is always transverse (Fig. 1), whereas these inflorescences are always median, which must be the case, as two out of the three flowers composing it are seated in the axils of the cquivalents $(l, l)$ of the two foliage-leaves, which are always median. The uppermost pair of leaves preceding the terminal flowers $(s, s)$ in such cases is therefore not equivalent to the uppermost sterile pair of leaves $\left(s^{1}, s^{1}, \mathrm{Fig} .1\right)$ in the female inflorescence. If, again, both the lateral flowers and their bracts are suppressed (Fig. $8 \mathrm{II}$ ), the resulting inflorescence is exactly like the normal male inflorescence, differing only in its relative position to the mother-axis and the bract of the shoot.

1 Neue 13eitrïge, i. p. 553. I an quoting here from lïiller, Blithendiatgramme, p. 553. 
In the female flowers the perianth ${ }^{1}$ consists usually of two dimerous alternating whorls of scale-leaves, which cohere, more or less, at the base. Their position will be readily understood by a glance at Fig. I, which has been copied from Eichler ${ }^{2}$. The two carpels which compose the ovary continue the regular alternation. No exception has come under my observation with regard to the number of parts composing the lateral flowers, whereats in the terminal flowers of shoots bearing three folinge-leaves only one whorl of perianth-leaves, alternating with the three scalc-leaves which precede the flowers, was observed (1 iig. 4). Wydler mentions a case in which a female terminal flower, preceled by two scale-leaves, hat also a trimerous perianth. An increase in the number of perianthlaves beyond four has also been described by the same athor, and is very likdy to be explaned in the same way as a similar increase of the organs composing the male flowers, which will be treated of later. Whether any variation in the number of carpels takes place I am unable to say.

The male flowers are, on the whole, built on the same plan as the female ones, but every trace of an ovary is absent in their centre. liatch perianth-leaf bears six to twenty pollen-sacs. Iofmeister" and van "Tieghem t consider each of these structures (taken as a whole) ats a single leaf. The former bases his view on the development, which shows that it arises apparently as one organ; while the latter bases his view chiefly on anatomical grounds, but he is careful to call them simply polliniferous sepals ("sépales pollinifires'); he does not call them stamens, as one would expect. Lichler, on the other hand, who based his vicw on a comparison between the structure of the flower of the mistletoe and that of nearly allied forms, came to the conclusion that each consists of two parts, namely of

'I have never seen the so-cnlled 'calyculus' of the flowers. It is frequently mentioned that it does not oecur regularly, and it seems to be certain that it is only an ongrgowth of the axis without lenfy chanacter. Compare Hofmeister in Florn, 1854, p. 644 (note); Wydler, in Irlorn, 1860, p. 445; Tichler, Bliithendiagramme, 13.553 .

2 1. c., ligg. $23^{6}, 13$.

- Ann, d. Sc. Nal. súrie 5, 'Tome xii. p, ror.

il 1. c., p. 539 . 
a perianth-leaf and an anther. I am inclined to think that his view is right, although I cannot offer much alditional evidence to support it. I3ut I may mention that I have often seen the posterior perianth-leaf of lateral flowers forming a compatet body with the aldoining perianth-leaf of the terminal flower, both of them bearing their pollen-sacs in their proper places. Now, when we thus see that leaves of different flowers frequently conlesce to form a single structure, we are certainly justified from a morphological point of vicw to assume that such a coalescence maty constantly take platec in the leaves of the same flower, if thereare other reasons to support such an assumption. Fichler adduces as an argument in stpport of his view the fact: that in other species of Viscem, ats also in the neatly allied

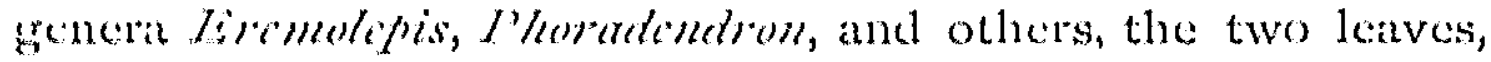
which are only hypothetical in our species, mat actually become nearly sepratite; and, further, thatt it also happens exeeptionally in these genera that the flowers possess three perianth-leaves and two anthers, one of the latter being then placed between two of the former, "certainly the best cvidence agranst ITofmeister's vicw "."

Tiichler says that the male lateral flowers are 'always" tetramerous, but I found them frecuently to be trimerous or even pentamerous. In the trimerous flowers there was apparently a single whol of perianth-leaves ${ }^{2}$ substituted for the normal two dimerous whorls, whereas in the pentamerous fowers evidently a splitting of a perianth-leaf with the adnate stamen hacl taken place (compare the cliagrams of the lateral flowers in Figr. 6). The terminal fowers of shoots with a climerous (and I may add also those with a tetramerous) whorl

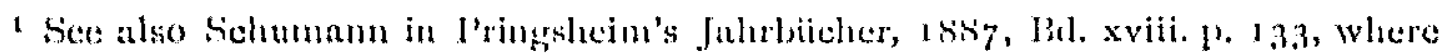
questions of this kind are treated of in a more general way; the eatse of 1 Fiscum is mentioned on 1\%. 17o. My pajer was in the hands of the editors before No, VI, of the Anmals of Hotany was published, I have noticed with satisfaction that

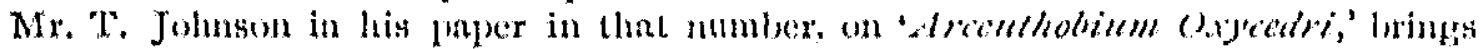
forwatl very strong arguments in support of bidhler's view (d. Annals of botany, Vol. TI. No. VI. 1P. I 55 and 156 ).

" for shortness' sake If am only speaking of perinnth-lenves here and in the following pasenges. It will be understodel that I always mean the structures composed of a perianth-lear and an anther. 


\section{of the Mistlctoo (Viscum album, L.).}

of foliagre-leaves are usually tetramerous, the outer whorl of perianth-leaves being median, and, therefore, differing in this respect from the terminal female flowers, as will be seen when Fig. I. and Fig. a are compared. It will also be seen that the outer whorl of pertinth-leaves of the male flowers has the sime relittive position als the uppermost pair of scalc-leaves in the female oncs. The terminal male flowers of shoots with three folinge-leaves usually possess two trimerous whorls of perianth-leaves, the outer one having also the relative position of the three scalc-leaves in the corresponding female flowers. lichler is of opinion that in the common male terminal flowers the two scalc-letves which precede the female flowers are mate use of ("werden einbe\%ogen') in the formation of the perianth. Nlthough at first sight this appears obvious, I cannot anges with such an interpetation. First of all it maty be arguted, from a general point of vicw, that the outer and first formed perianth-leaves talke a meclian position, simply becatuse there is room for them to develop in this position on account of the scalc-leaves being absent. If we aclopt lichler's view we must further admit that the male terminal flower is constintly without the inner dimerous whorl of perianth-leaves which the corresponding female flower always possesses. But there is, thirdly, one reason which directly compels us to give up the view brought forward by Gichler. I have alreaty mentioned that dormant buds often produce inforescences composed of a various number of flowers. I have described the three cases which are the most frequent. Let us compare the two cases represented in Fig. 8 I and II. These two infloresecences were found side by side. It will be aclmitted that in these two cases the terminal flowers are absolutely equivalent, and yet, if we examine the relative position of their parts, we notice the actual difference which exists between the normal male and female terminal flowers. If, as in Iig. $8 \mathrm{I}$, the terminal flower is preceded by two sterile scalc-lcaves, the outer whorl of perianth-leaves is median, and thus alternates with them; but if it is not preceded by them,

It must be said that the ficrman expression is rather vague. 
as in Ifig. $8 \mathrm{II}$, this whorl is placed transversely, assuming the position of the scalcmleaves which are wanting. I have tested this fact in many cases, and always with the same result. I am thus led to believe that the difference between the terminal male and female flowers, with regard to the position of their parts, is simply caused by the complete suppression in the former of the uppermost (fourth) pair of leaves.

$\Lambda \mathrm{n}$ increase in the number of parts composing the male terminal flowers is not rare. Eichler only knew of pentamerous and hexamerous flowers besicles the normal ones; but I have also observed one heptamerous and one decamerous flower ${ }^{1}$. Fichler explained the abnormal cases known to him by assuming that in the hexamerous flowers the inner dimerous whorl of normal flowers was replaced by a whorl of four members, and in the pentamerous flowers by a whorl of three; but his own figure, which I have copied (Fig. 9), suggrests at once the idca that the increase is simply due to the splitting of the two normal members composing the inner whorly. I have already adopted such an cxplanation in the case of the pentamerous lateral flowers, where I usually found it to agree extremely well with the position of the parts of the flowers. In the terminal flowers a regular arrangement of the parts cannot always be recognised when their number has been increased, but it is easy to find all intermediate stages between perianth-leaves only slightly divicled at the top, and others which are divided down to the base. My explanation covers also the cases in which seven and ten perianth-leaves were found, whereas those adopting Eichler's view would find difficulty in explaining them. The view that the increase is due to splitting may perlaps be strengthened still more when I restate the fact, which I hope has been distinctly proved, that splitting of foliage-leaves also occurs in the mistletoc.

1 The hexamerous flowers of shoots with three folinge-leaves were also npjurently unknown to him, but these must be left out of account here, as in a certain sense they have to be consillered as nomal.

" I may here call attention to the similarity between our cnse and the interpiretation of the nuchroceium of Cruclferae, regarding which Eichler holds exactly the: view I take of it in $V$ isctm. 


\section{IEXPLANATION OF FIGURES IN TLATE XVIT.}

Illustrating T)r. Sichinland's paper on the Morphology of the Mistletoe (Fistum allum, 1.).

rAll figures represent dingrams of flowering shoots as actually observed by the atthon, with the exception of ligk 9.)

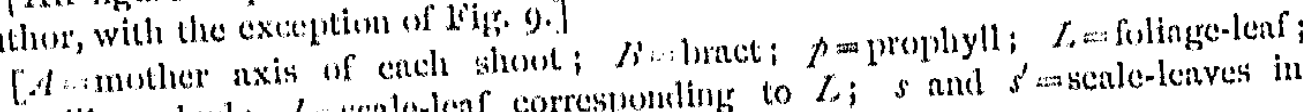

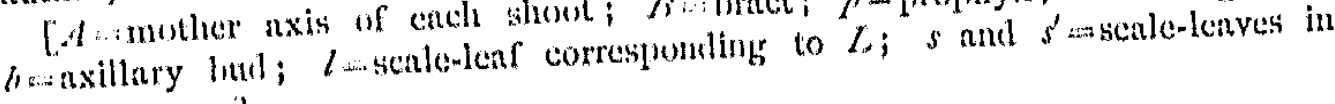
inflorescences.)

liigr. I. Normal female shout (after lishler).

likg. 2. Normal male shout.

lizg. 3. Mate shont in which the posterior folinge-lend has split into two; the

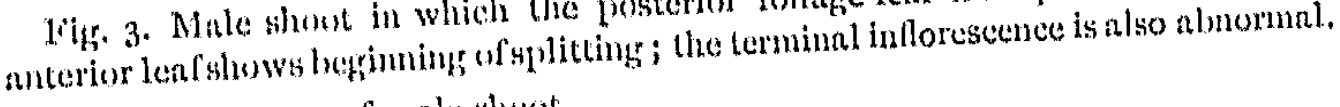

Fig. A. Trimorous female shoot.

Iit. 5. T. 'Trimerous male shoot; one latend flower is not developed. II. Tetratmerous male shont; one laternl flower and the terminal flower are not developet. 'The two melinn lateral flowers are trimerous, ant oceupy the apex of the shoot.

litg. 6. 'Jetranerons male shoot; one lateral flower is trimerous, another pentamerotis.

liig. 7. Male shoot with five flowers derelopet from a dormant but. In the phec of the two folinge-leaves, scale-lenves are developed which also bens flowers in their axils,

liig. 8. I. $A$ similar case as represented in ligr. 7 , only the two lateral fluwers are supprested. II. Case similar to the freceling one: n further reduction has taken place liy the suppression of the uppermost pair of sente-teaves.

liig. 9. Male shoot with hexamerous terminal flower (after Eichler). 
Annats of Botany

Fig. 1.

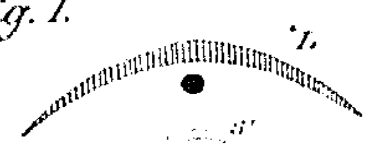

Füg.

Fig. 3. OA

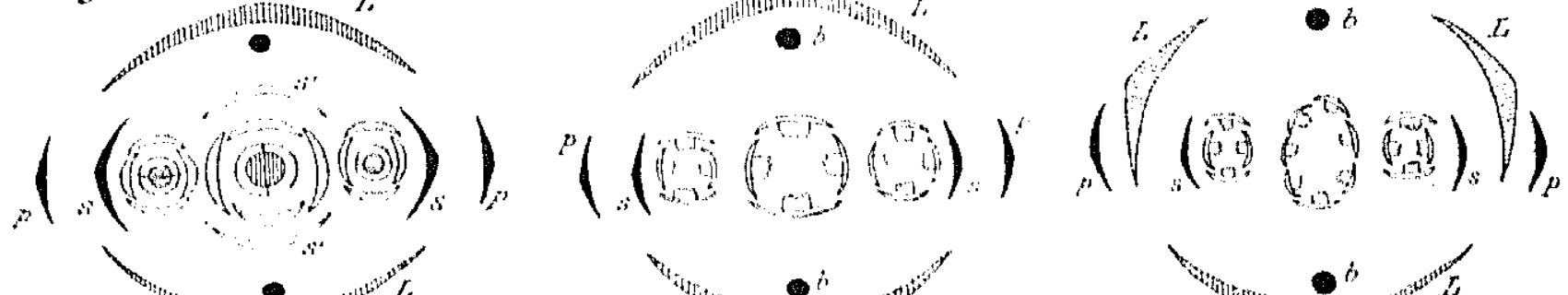
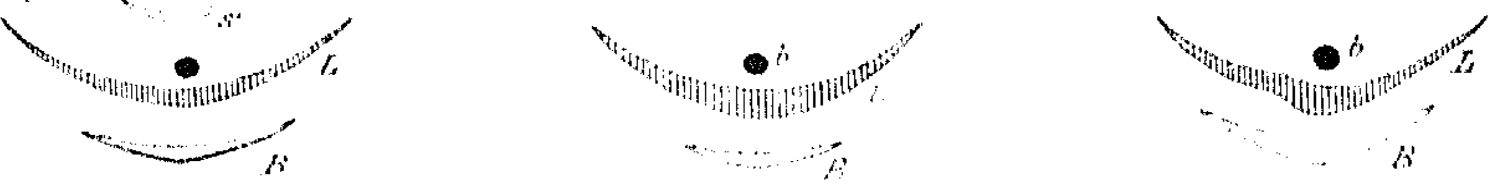

rig. \%.

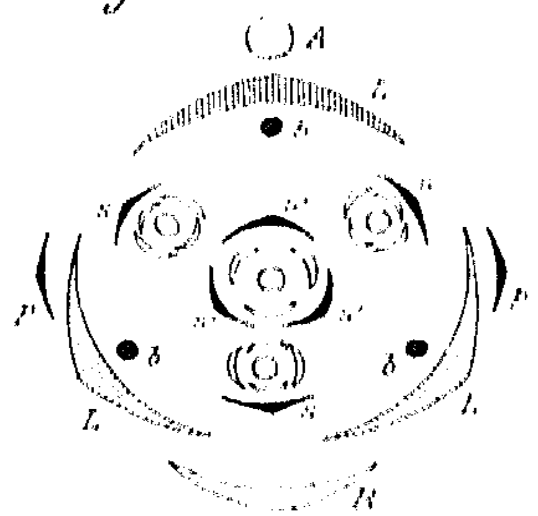

firg. o.

Figy $\%$
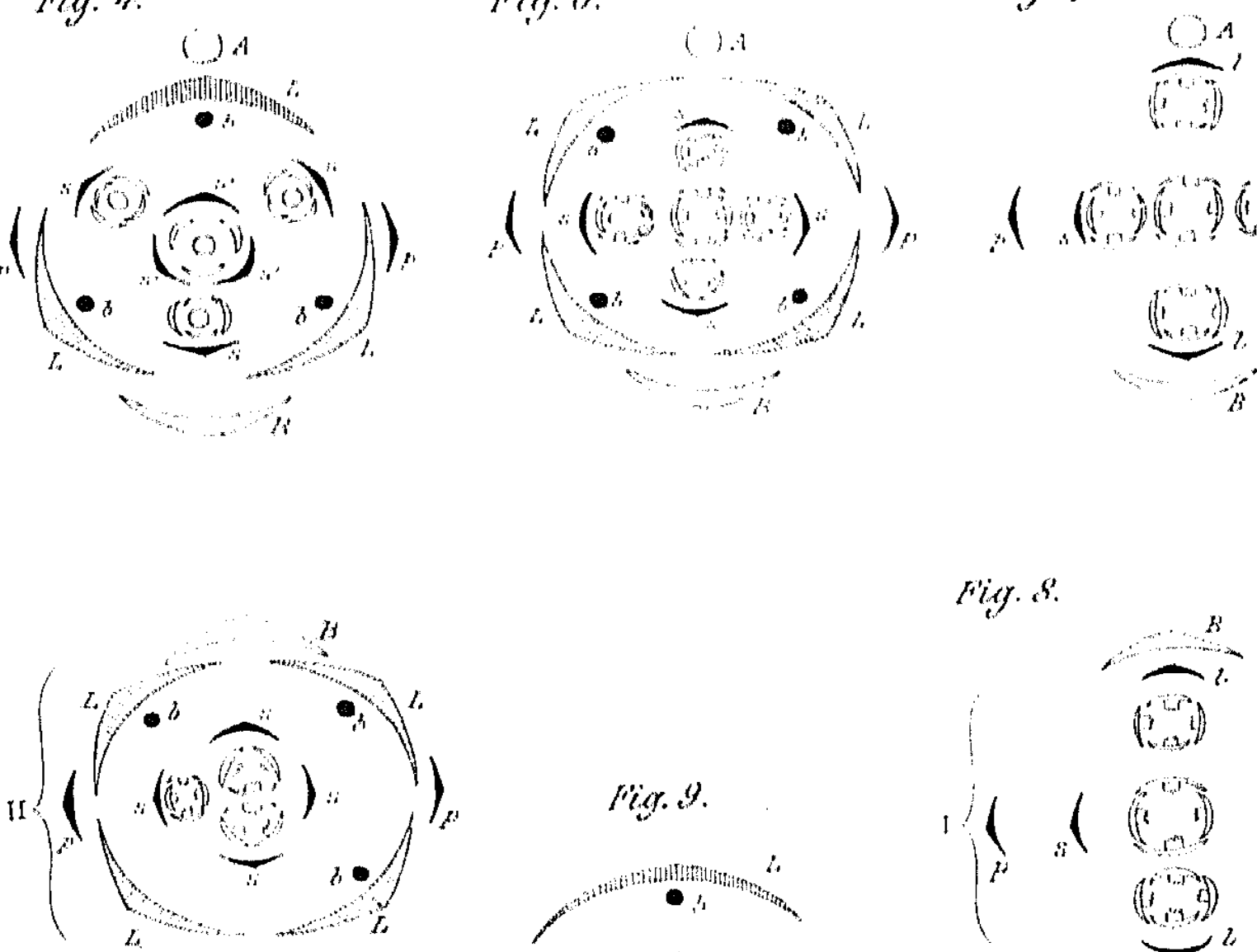

fing. s.
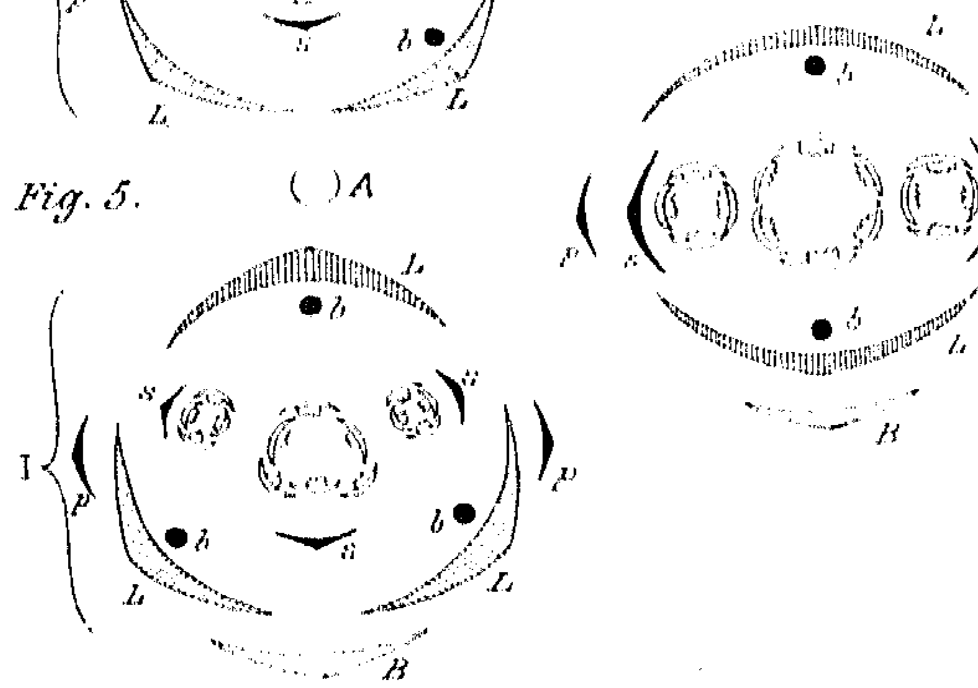

fige.

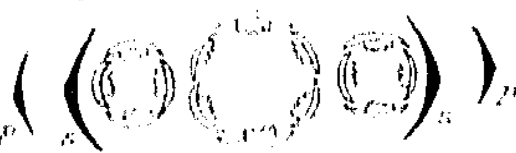
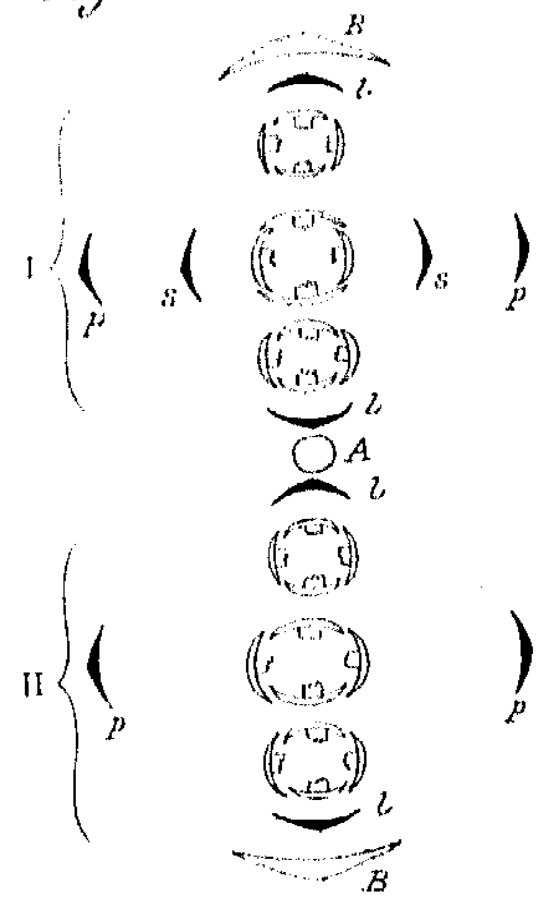

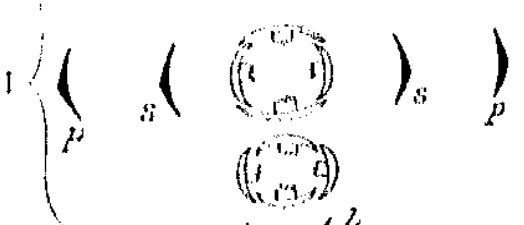

University Press, Oxford.

Schönland dol.

SCHÖNLAND.- ON THE MORPHOLOGY OF THE MISTLETOE. 